\title{
Total, chemical, and biological oxygen consumption of the sediments in the Ziya River watershed, China
}

\author{
Nan Rong ${ }^{1,2}$ • Baoqing Shan ${ }^{1}$ \\ Received: 26 November 2015 / Accepted: 21 March 2016 / Published online: 30 March 2016 \\ (C) Springer-Verlag Berlin Heidelberg 2016
}

\begin{abstract}
Sediment oxygen demand (SOD) is a critical dissolved oxygen (DO) sink in many rivers. Understanding the relative contributions of the biological and chemical components of SOD would improve our knowledge of the potential environmental harm SOD could cause and allow appropriate management systems to be developed. A various inhibitors addition technique was conducted to measure the total, chemical, and biological SOD of sediment samples from 13 sites in the Ziya River watershed, a severely polluted and anoxic river system in the north of China. The results showed that the major component of SOD was chemical SOD due to iron predominate. The ferrous SOD accounted for 21.6-78.9\% of the total SOD and $33.26-96.79 \%$ of the chemical SOD. Biological SOD represented $41.13 \%$ of the overall SOD averagely. Sulfide SOD accounted for $1.78-45.71 \%$ of the total SOD and it was the secondary predominate of the chemical SOD. Manganous SOD accounted for $1.2-16.6 \%$ of the total SOD and it was insignificant at many sites. Only four kinds of benthos were collected in the Ziya River watershed, resulting from the low DO concentration in the sediment surface due to SOD. This study would be helpful for understanding and preventing the potential sediment oxygen depletion during river restoration.
\end{abstract}

Responsible editor: Philippe Garrigues

Baoqing Shan

rongnan1112@163.com

1 State Key Laboratory on Environmental Aquatic Chemistry, Research Center for Eco-Environmental Sciences, Chinese Academy of Sciences, Beijing 100085, China

2 University of Chinese Academy of Sciences, Beijing 100049, China
Keywords Sediment oxygen demand · Fractionation Chemical SOD · Biological SOD · Contribution · Ziya River watershed

\section{Introduction}

Rivers around the world are being intensely affected by human activities. Many streams in the world are confronting with extensive drying and intermittent flow, oxygen depletion, water pollution, and aquatic ecosystem degeneration. Problems associated with low dissolved oxygen (DO) concentrations in rivers have been recognized for over a century (Cox 2003). Contaminated sediment in a polluted river strongly affects the quality of the overlying water, especially consuming oxygen in water. In loading masses of organic matter rivers, the oxygen consumption is more prominent. Sediment oxygen demand (SOD) is a component of the DO balance in natural water bodies, such as rivers, lakes, and reservoirs, and has long been known to significantly affect the DO cycle in the overlying water. SOD has been defined as the rate of oxygen consumption in the sediment (Veenstra and Nolen 1991). This indicator is important, because SOD rate is often assumed or estimated in water quality modeling studies that are used to set discharge limits. The amount of $\mathrm{O}_{2}$ taken up by the sediment largely governs $\mathrm{O}_{2}$ depletion in water bodies with organic-rich sediment (Raun et al. 2010). SOD can account for more than $50 \%$ of the total oxygen consumption in a water body, such as the Arroyo Colorado River (Matlock et al. 2003) and the Tarawera, a shallow mobile-bed river (Rutherford et al. 1991). This leads to SOD a critical element in a water system. It is therefore necessary to estimate the oxygen demands of sediments in aquatic systems.

The SOD depends on oxygen being transferred from the water column to the sediment and on the microbial and 
chemical consumption of oxygen within the sediment (Higashino et al. 2004; Matzinger et al. 2010), so the SOD is usually divided into two components, the biological SOD and the chemical SOD (Bowman and Delfino 1980). The biological SOD includes the oxygen demand of all of the organisms living in the sediment (i.e., including microbial and macrobial respiration). Anaerobic mineralization processes in relatively deep sediment layers produce various reduced inorganic products. These products diffuse to the oxic-anoxic interface and consume oxygen that is present in the oxic sediment (Bak and Pfennig 1991; Urban et al. 1994). Thus, the chemical SOD is the oxygen demand of reactive, reduced elements and substances in the sediment (e.g., $\mathrm{Fe}^{2+}, \mathrm{Mn}^{2+}$, and $\mathrm{S}^{2-}$ ) that can quickly become oxidized in the presence of $\mathrm{O}_{2}$ and therefore produce an oxygen demand (Bak and Pfennig 1991; Urban et al. 1994). The biological SOD and chemical SOD are usually distinguished by measuring the SOD of sterilized sediment by employing different toxicants to suppress biological activity (Barcelona 1983; Wang 1980). The toxicants include $1 \%$ buffered formaldehyde, $0.5 \sim 1 \mathrm{M}$ phenol, $10^{-5} \sim 0.5 \mathrm{M}$ potassium cyanide, $30 \mathrm{~g} / \mathrm{L}$ sodium chloride, and mercuric chloride. The chemical SOD can be further divided into oxygen consumed by $\mathrm{Fe}^{2+}$, oxygen consumed by $\mathrm{Mn}^{2+}$, and oxygen consumed by $\mathrm{S}^{2-}$, which can be measured using different inhibitors. With the exception of Wang's study, few attempts have been made to assess the importance of the different reduced chemical components to overall SOD.

The Ziya River watershed is the most polluted sub-basin of the Hai River Basin in China. The oxygen conditions in many parts of the Ziya River watershed have been severely deteriorated. Malodorous and blackwater streams, characterized by emitting uncomfortable color and odor, are common and dominant hydrological features of the Ziya River watershed. As is generally the case, the blackwater streams are slow-moving (limiting the amount of reaeration that can occur), and relatively little photosynthesis occurs in the water because the water is darkly colored and shaded by overhead objects (Todd et al. 2009). Blackwater streams also have extremely low DO concentrations (Todd et al. 2010). The Ziya River watershed receives $112.8 \times 10^{3} \mathrm{t}$ of COD and $9.1 \times 10^{3} \mathrm{t}$ of ammonia each year. The DO concentrations in the Ziya River watershed are often lower than $8.0 \mathrm{mg} / \mathrm{L}$, and in many streams, the DO concentrations are below the Chinese Class V water standard $(2.0 \mathrm{mg} / \mathrm{L})$. The oxygen demand in the water column of the Ziya River has received much attention from many researchers, but the oxygen demand in the sediment has received relatively little attention up to now.

In sediments of the Ziya River watershed, oxygen is generally depleted in the overlying water. Little information on the SOD and the processes that consume oxygen in the sediment has been obtained. In this study, we added different inhibitors to bottom sediment samples from the Ziya River watershed to differentiate between the biological SOD and chemical SOD and to separately measure the different fractions of the chemical SOD. This allowed us to determine the proportion of the SOD that could be attributed to bacteria and to reduced inorganic species $\left(\mathrm{Fe}^{2+}, \mathrm{Mn}^{2+}\right.$, and $\left.\mathrm{S}^{2-}\right)$. The results will be applied to assess the different SOD components of bottom sediments and to identify the processes that most contribute to the SOD in the Ziya River watershed. The potential environmental effects of sediment oxygen consumption processes will also be discussed. The results of the study will be useful for sediment treatment of anoxic river and the development of management strategies for the basin.

\section{Materials and methods}

\section{Sample sites}

The Ziya River watershed is in the central part of the Hai River Basin in North China, as shown in Fig. 1. The Ziya River watershed is a complex river system that receives domestic wastewater and effluents from sewage treatment plants and a range of industries. It was suffering from quite serious pollution, which poses severe threats to ecological systems. We established 13 sampling sites (shown in Fig. 1) in the plain area of the Ziya River watershed in August 2013 and measured the SOD fractions in sediment samples from these sites. The point-setting principle was grid method combined with field investigation. Sites S01-S04 were on the Shunshui River and the Li River around Xingtai City in the upstream part of the Ziya River watershed. Sites S05-S08 were on the Xiao River around Shijiazhuang City in the midstream part of the Ziya River watershed. Sites S09-S12 were on the Shaocun Canal around Xinji City (in the midstream part of the Ziya River watershed). Site S13 was on the Fuyang River near Hengshui City in the downstream part of the Ziya River watershed.

\section{Sediment collection and SOD fractionation}

Three surface sediment samples (to about $5 \mathrm{~cm}$ deep) were collected from not less than $500 \mathrm{~m}$ away from each other at each site, using a dredge sampler, in May 2014. Sediment samples were stored in polyethylene tubes, with air-isolating cocks, to reduce the likelihood of sediment oxidization during the preservation period. The samples were kept at $-20^{\circ} \mathrm{C}$ until analysis, and the SOD measurements were made as soon as possible after the samples had reached the laboratory. Some quality indicators of the water and the sediment, including the DO concentration, $\mathrm{pH}$, and oxidation reduction potential (ORP), were measured using appropriate electrodes during the sampling procedure. The organic matter (OM), Fe(II), and acid-volatile sulfide (AVS) concentrations in each sediment sample were determined in the laboratory. The amount 
Fig. 1 Map of the Ziya River watershed, China, showing the sample sites

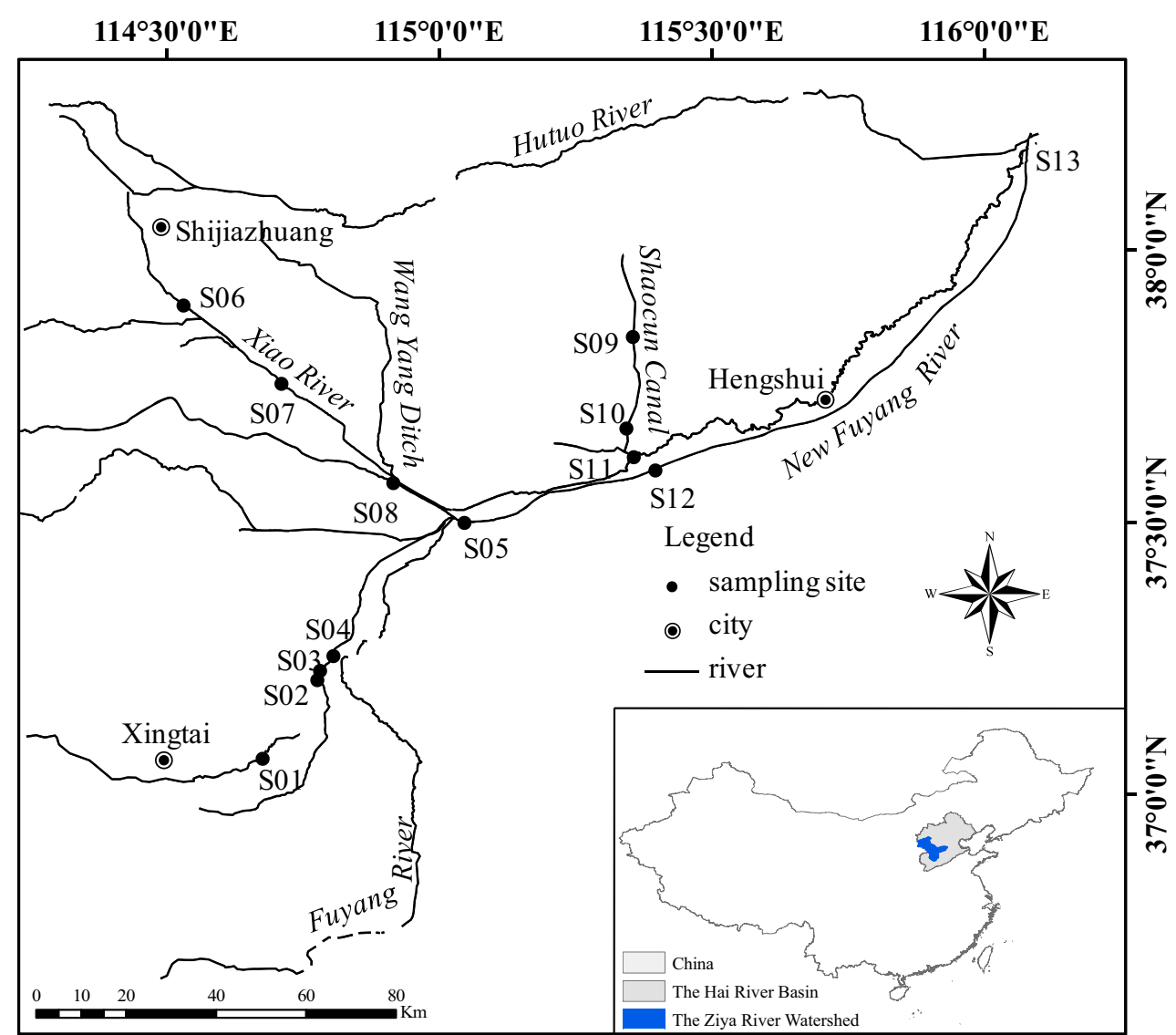

of organic matter in each sediment sample was determined from the loss of weight on ignition, and the results were expressed as a percentage of the dry sediment mass. The water content (defined as weight loss after $24 \mathrm{~h}$ at $105^{\circ} \mathrm{C}$ ) of each sample was measured to calculate the sediment dry weight. The Fe(II) concentration was determined photometrically using the ferrozine method (Grashoff et al. 1983). AVS was extracted using the diffusion method and determined using an ion-selective electrode (Hsieh and Yang 1989; Jia et al. 1998). Quantitative and qualitative samplings of benthos were conducted at the same time. The qualitative sampling was taken using a standard D-net. The quantitative sampling was processed with a surber. Samples were preserved with $10 \%$ formalin in the field, and then transformed to $75 \%$ ethanol in the laboratory. Benthos was normally identified to the maximum possible level by anatomical lens.

Each sediment sample was transferred to poly(methyl methacrylate) cylinders before the fractionation tests were performed. A poly(methyl methacrylate) tube was inserted to a polyethylene tube with $10-\mathrm{cm}$ depth, then the sediment core within the cylinder was $10 \mathrm{~cm}$ deep and was covered with around $14 \mathrm{~cm}$ of overlying water. Each cylinder had an inner diameter of $6 \mathrm{~cm}$ and a height of $28 \mathrm{~cm}$. A rubber stopper was fitted to each end of the core to stop water and sediment leaking out. There was about $400 \mathrm{~mL}$ of deionized water in each cylinder. A blank experiment showed that there were few oxygen consumption substances in the deionized water. The DO concentration in the overlying water in each cylinder was recorded manually using a portable hand-held DO meter. An electrode in the overlying water was connected to the DO meter through a hole in the upper rubber stopper. The rubber stoppers were fastened together with two rubber bands fitted parallel to the length of the cylinder to prevent air entering the cylinder. All the fractionation tests were conducted in a laboratory with constant temperature and constant humidity. The temperature was controlled at $20^{\circ}$ by an air conditioner.

A method for fractionating SOD into biological and chemical demands and for further fractionating the chemical SOD into ferrous, manganese, and sulfide components has previously been proposed (Wang 1980). Few means have been applied to fractionate SOD except Wang's research. The detailed fractionation procedure is shown in Fig. 2. The components are shown in the figure using the abbreviations $\mathrm{Fe}^{2+}$.SOD for the ferrous SOD, $\mathrm{Mn}^{2+}$.SOD for the manganous $\mathrm{SOD}$, and $\mathrm{S}^{2-}$.SOD for the sulfide SOD. Detailed serial measurements were performed using three cylinders for each sample. The total SOD was measured, when no toxicant had been added, by comparing the initial oxygen concentration in the core and the oxygen concentration after $2 \mathrm{~h}$ had elapsed. Biological oxygen consumption was then stopped by adding 


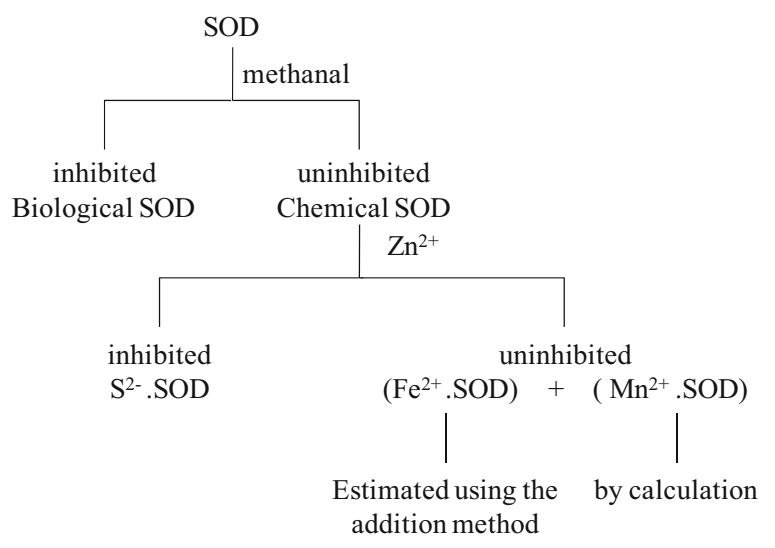

Fig. 2 Outline of the sediment oxygen demand (SOD) fractionation procedure (Wang 1980)

$10 \mathrm{~mL}$ of a concentrated methanal solution to the overlying water using a syringe (through a small hole in the rubber stopper that was kept closed during the measurements) to give a final methanal concentration in the overlying water of $1 \%$ (the same as conventionally used by aquatic biologists to preserve water samples). Once the toxicant had been added, the sample was mixed for $1 \mathrm{~min}$, then the initial DO concentration was recorded using an oxygen electrode. The final DO concentration was determined after the sample had been incubated for $2 \mathrm{~h}$. The amount of DO that had been used in this 2-h period was used to determine the chemical SOD. The difference between the total SOD and the chemical SOD was defined as the biological SOD. To separate sulfide SOD from ferrous and manganous SOD, the sulfide was removed by zinc solution $(1.3 \mathrm{ml}$ of $1 \mathrm{~mol} / \mathrm{L})$. Then the sulfide SOD was calculated by subtracting the sum of the ferrous SOD and manganous SOD from the chemical SOD. The ferrous SOD was estimated using the ferrous iron addition method. One milliliter of $0.05 \mathrm{~mol} / \mathrm{L}$ ferrous ammonium sulfate was added to the first cylinder, $2 \mathrm{~mL}$ of $0.05 \mathrm{~mol} / \mathrm{L}$ ferrous ammonium sulfate was added to the second cylinder, and $3 \mathrm{~mL}$ of $0.05 \mathrm{~mol} / \mathrm{L}$ ferrous ammonium sulfate was added to the last cylinder in the ferrous iron addition tests. The manganous SOD was determined by computing the difference from chemical SOD. Each experiment was performed in triplicate, and the mean values are presented.

\section{Results}

\section{Sediment properties}

The DO concentrations, $\mathrm{pH}$ values, ORP, $\mathrm{Fe}(\mathrm{II})$ concentrations, and AVS concentrations that were found are shown in Table 1 . The DO concentrations in the overlying water were lower than $8.0 \mathrm{mg} / \mathrm{L}$, the range being $0.13-7.76 \mathrm{mg} / \mathrm{L}$ and the mean $3.08 \mathrm{mg} / \mathrm{L}$. The Chinese Class III water standard DO
Table 1 Characteristics of the sediment samples used in the study

\begin{tabular}{|c|c|c|c|c|c|c|c|c|}
\hline \multirow[t]{2}{*}{ Site } & \multicolumn{3}{|l|}{ In water } & \multicolumn{5}{|c|}{ In sediment } \\
\hline & $\begin{array}{l}\mathrm{DO} \\
(\mathrm{mg} / \mathrm{L})\end{array}$ & $\mathrm{pH}$ & $\begin{array}{l}\text { ORP } \\
(\mathrm{mV})\end{array}$ & $\mathrm{pH}$ & $\begin{array}{l}\text { ORP } \\
(\mathrm{mV})\end{array}$ & $\begin{array}{l}\mathrm{OM} \\
(\%)\end{array}$ & $\begin{array}{l}\mathrm{Fe}(\mathrm{II}) \\
(\mathrm{g} / \mathrm{kg})\end{array}$ & $\begin{array}{l}\text { AVS } \\
(\mathrm{g} / \mathrm{kg})\end{array}$ \\
\hline S01 & 5.7 & 7.54 & 99 & 7.52 & -394 & 8.23 & 16.22 & 6.96 \\
\hline S02 & 4.92 & 7.4 & 109 & 7.65 & -161 & 11.60 & 1.86 & 1.21 \\
\hline S03 & 3.14 & 7.48 & 134 & 7.18 & -206 & 16.29 & 18.47 & 4.01 \\
\hline S04 & 1.65 & 7.44 & 135 & 7.05 & -396 & 6.51 & 14.75 & 8.89 \\
\hline S05 & 3.37 & 7.26 & 128 & 7.22 & -375 & 16.56 & 9.31 & 8.57 \\
\hline S06 & 2.74 & 7.42 & 102 & 7.23 & -375 & 2.73 & 6.00 & 0.01 \\
\hline S07 & 5.37 & 7.53 & 168 & 7.19 & -276 & 1.52 & 2.83 & 0.00 \\
\hline S08 & 0.13 & 7.49 & -49 & 7.41 & -317 & 3.16 & 7.92 & 0.46 \\
\hline S09 & 0.34 & 7.19 & 19 & 6.38 & -403 & 12.19 & 9.03 & 25.77 \\
\hline $\mathrm{S} 10$ & 0.19 & 6.71 & -61 & 7.01 & -287 & 10.90 & 13.66 & 19.40 \\
\hline S11 & 7.76 & 7.13 & 137 & 6.86 & -363 & 18.22 & 13.49 & 17.89 \\
\hline $\mathrm{S} 12$ & 2.13 & 7.06 & -75 & 6.99 & -278 & 9.02 & 8.23 & 14.40 \\
\hline $\mathrm{S} 13$ & 2.66 & 7.84 & 91 & 7.13 & -176 & 6.29 & 3.29 & 10.40 \\
\hline
\end{tabular}

concentration is $5.0 \mathrm{mg} / \mathrm{L}$, and the DO concentrations were lower than that concentration in water from $77 \%$ of the sampling sites. The $\mathrm{pH}$ of the overlying water samples ranged from 6.71 to 7.84 , and the $\mathrm{pH}$ of the sediment samples ranged from 6.38 to 7.65 . The sediment $\mathrm{pH}$ was a little lower than the overlying water $\mathrm{pH}$ at most of the sites. The overlying water ORP was positive except at three sites, and the range was -75 to $168 \mathrm{mV}$. The sediment ORP was negative at all of the sites, and the range was -403 to $-161 \mathrm{mV}$. The OM contents of the sediment samples were $1.52-18.22 \%$ dry weight. The mean $\mathrm{Fe}(\mathrm{II})$ concentration in the sediment samples was $9.62 \mathrm{~g} / \mathrm{kg}$ wet weight, and the range was $1.86-18.47 \mathrm{~g} / \mathrm{kg}$ wet weight. The Fe(II) concentrations were generally at least 10 times higher in the S03 sediment samples than in the S02 sediment samples. The AVS concentrations in the sediment samples from sites S01-S05 and S09-S13 were $1.21-25.77 \mathrm{~g} / \mathrm{kg}$ wet weight, but less than $1 \mathrm{~g} / \mathrm{kg}$ from sites S06, S07, and S08. The mean AVS concentration in the sediment samples was $9.07 \mathrm{~g} / \mathrm{kg}$ wet weight. The Fe(II) and AVS concentrations at the different sites were rather different, and the concentrations were mainly influenced by the ambient ORP.

\section{Fractionations of SOD and their contributions to SOD}

The total, chemical, and biological SOD are presented in Table 2. The mean SOD decreased in the order biological SOD $>$ ferrous $\mathrm{SOD}>$ sulfide $\mathrm{SOD}>$ manganous SOD. The biological SOD contributed $41.13 \%$, the ferrous SOD contributed $38.67 \%$, the sulfide SOD contributed $15.63 \%$, and the manganous SOD contributed $4.57 \%$ of the total SOD. The total SOD at all of the sites varied through the study period, the range being 0.459 and $1.907 \mathrm{~g} / \mathrm{m}^{2} /$ day and the mean being 
Table 2 Fractions of the sediment oxygen demand (SOD, in $\mathrm{g} / \mathrm{m}^{2} /$ day) found in the samples from the different sites

\begin{tabular}{|c|c|c|c|c|c|c|}
\hline \multirow{2}{*}{$\begin{array}{l}\text { Sample } \\
\text { site }\end{array}$} & \multirow{2}{*}{$\begin{array}{l}\text { Total } \\
\text { SOD }\end{array}$} & \multirow{2}{*}{$\begin{array}{l}\text { Biological } \\
\text { SOD }\end{array}$} & \multirow{2}{*}{$\begin{array}{l}\text { Chemical } \\
\text { SOD }\end{array}$} & \multicolumn{3}{|l|}{ Chemical SOD } \\
\hline & & & & $\mathrm{Fe}^{2+} \cdot \mathrm{SOD}$ & $\mathrm{Mn}^{2+} \cdot \mathrm{SOD}$ & $\mathrm{S}^{2-} . \mathrm{SOD}$ \\
\hline S01 & $1.128^{\mathrm{a}}$ & $0.414(36.68)^{\mathrm{b}}$ & $0.714(63.32)$ & $0.600(53.21)$ & $0.046(4.08)$ & $0.068(6.03)$ \\
\hline S02 & 0.459 & $0.085(18.52)$ & $0.374(81.48)$ & $0.362(78.87)$ & $0.012(2.61)$ & n.d. \\
\hline S03 & 0.595 & $0.153(25.71)$ & $0.442(74.29)$ & $0.147(24.71)$ & $0.023(3.87)$ & $\begin{array}{l}0.272 \\
\quad(45.71)\end{array}$ \\
\hline S04 & 0.893 & $0.281(31.44)$ & $0.612(68.56)$ & $0.362(40.55)$ & $\begin{array}{l}0.148 \\
\quad(16.58)\end{array}$ & $\begin{array}{l}0.102 \\
\quad(11.43)\end{array}$ \\
\hline S05 & 0.476 & $0.238(50.00)$ & $0.238(50.00)$ & $0.192(40.34)$ & $0.012(2.52)$ & $0.034(7.14)$ \\
\hline S06 & 0.578 & $0.068(11.76)$ & $0.510(88.24)$ & $0.306(52.94)$ & $0.034(5.88)$ & $\begin{array}{l}0.170 \\
\quad(29.41)\end{array}$ \\
\hline S07 & 1.309 & $0.833(63.64)$ & $0.476(36.36)$ & $0.283(21.62)$ & $0.057(4.35)$ & $\begin{array}{l}0.136 \\
\quad(10.39)\end{array}$ \\
\hline S08 & 0.553 & $0.315(56.92)$ & $0.238(43.08)$ & $0.176(31.86)$ & $0.028(5.07)$ & $0.034(6.15)$ \\
\hline S09 & 1.907 & $0.955(50.07)$ & $0.952(49.93)$ & $0.895(46.94)$ & $0.023(1.21)$ & $0.034(1.78)$ \\
\hline S10 & 1.887 & $0.731(38.74)$ & $1.156(61.26)$ & $0.476(25.22)$ & $0.034(1.80)$ & $\begin{array}{l}0.646 \\
\quad(34.23)\end{array}$ \\
\hline S11 & 1.131 & $0.587(51.88)$ & $0.544(48.12)$ & $0.340(30.08)$ & $0.034(3.01)$ & $\begin{array}{l}0.170 \\
\quad(15.04)\end{array}$ \\
\hline $\mathrm{S} 12$ & 0.850 & $0.476(56.00)$ & $0.374(44.00)$ & $0.226(26.59)$ & $0.046(5.41)$ & $\begin{array}{l}0.102 \\
\quad(12.00)\end{array}$ \\
\hline $\mathrm{S} 13$ & 1.139 & $0.493(43.28)$ & $0.646(56.72)$ & $0.340(29.85)$ & $0.034(2.98)$ & $\begin{array}{l}0.272 \\
\quad(23.88)\end{array}$ \\
\hline Mean & 0.993 & $0.433(41.13)$ & $0.560(58.87)$ & $0.362(38.67)$ & $0.041(4.57)$ & $\begin{array}{l}0.157 \\
\quad(15.63)\end{array}$ \\
\hline
\end{tabular}

$0.993 \mathrm{~g} / \mathrm{m}^{2} /$ day. The listed data of total oxygen consumption revealed the highest consumption at station S09 and S10. The biological SOD at all of the sites varied between 0.068 and $0.955 \mathrm{~g} / \mathrm{m}^{2} /$ day, and the mean was $0.433 \mathrm{~g} / \mathrm{m}^{2} /$ day. The biological SOD contributed between 11.76 and $63.64 \%$ of the total SOD. The chemical SOD at all of the sites varied between 0.238 and $1.156 \mathrm{~g} / \mathrm{m}^{2} /$ day, and the mean was $0.560 \mathrm{~g} /$ $\mathrm{m}^{2} /$ day. The chemical SOD contributed between 36.36 and $88.24 \%$ of the total SOD. The mean estimated ferrous SOD was $0.362 \mathrm{~g} / \mathrm{m}^{2} /$ day, and the range was $0.147-0.895 \mathrm{~g} / \mathrm{m}^{2} /$ day. The ferrous SOD contributed between 21.62 and $78.87 \%$ (mean $38.67 \%$ ) of the total SOD. The sulfide SOD varied greatly, ranging from 0.034 to $0.646 \mathrm{~g} / \mathrm{m}^{2} /$ day, and the mean was $0.157 \mathrm{~g} / \mathrm{m}^{2} /$ day. The mean contribution of the sulfide SOD to the total SOD was $15.63 \%$. The manganous SOD was not very different at the different sites except site S04, at which the manganous SOD was higher than elsewhere. The mean manganous SOD was $0.041 \mathrm{~g} / \mathrm{m}^{2} /$ day, and the mean contribution of the manganous SOD to the total SOD was $4.57 \%$. The manganous SOD was about one order of magnitude lower than the ferrous SOD and the sulfide SOD.

The biological SOD and chemical SOD (as estimated values and as percentages of the total SOD at the different sites) are plotted in Fig. 3. The biological SOD occurred at a slower rate than chemical SOD. Clear spatial variation in the total oxygen consumption at each site was distinguishable. The chemical SOD was higher than the biological SOD at seven sites, and the chemical SOD contributed between 36.36 and $88.24 \%$ of the total SOD. The chemical SOD was the dominant SOD fraction at all of the upstream sites (S01-S04). The total SOD increased between sites S02 and S04 along the flow direction of the river. The contributions of all components in chemical SOD were distinct. The ferrous SOD contributed 33.26-96.79\% of the chemical SOD and $21.62-78.87 \%$ of the total SOD. The ferrous SOD was the dominant component of the chemical SOD and contributed more than the biological SOD to the total SOD at sites S01, S02, S04, and S06. The sulfide SOD contributed 3.6-61.5\% of the chemical SOD and $1.78-45.7 \%$ of the total SOD. The sulfide SOD was higher than the ferrous SOD at site S03 and was the main contributor to the chemical SOD, and even to the total SOD, at this site. This could have been related to the high AVS concentration $(8.89 \mathrm{~g} / \mathrm{kg})$ in the sediment from site S03. The manganous SOD contributed $1.21-16.58 \%$ of the total SOD and 2.4-24.2\% of the chemical SOD. The highest manganous SOD occurred at site S04. The chemical SOD was the 
Fig. 3 a The rates of sediment oxygen demand (SOD) fractions and $\mathbf{b}$ the contribution percentage of the SOD fractions to the total SOD at different sample sites (a)

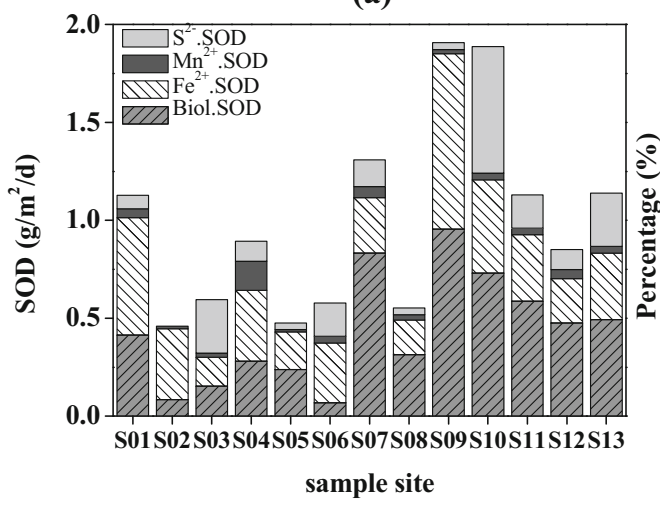

(b)

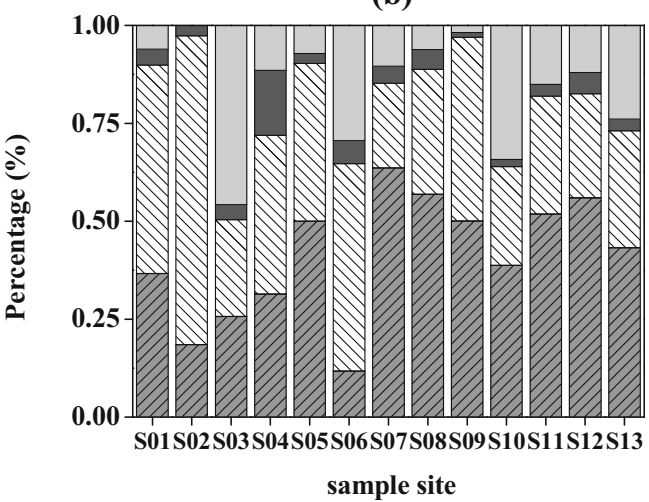

dominant contributor to the total SOD, and the ferrous SOD was the dominant contributor to the chemical SOD in the Ziya River watershed. The biological SOD contributed more to the total SOD at the midstream and downstream sites than at the upstream sites. The manganous SOD was insignificant at many sites.

\section{SOD fraction variations along rivers}

Changes in the magnitudes of the SOD fractions along the Shaocun Canal are shown in Fig. 4. The total SOD, biological SOD, and ferrous SOD gradually decreased moving from the upstream to the downstream. The total SOD decreased from $1.907 \pm 0.085 \mathrm{~g} / \mathrm{m}^{2} /$ day at $\mathrm{S} 09$ to $0.850 \pm 0.094 \mathrm{~g} / \mathrm{m}^{2} /$ day at S12 with $40.7 \%$ decrease. The biological SOD decreased by $38.6 \%$ from $0.955 \pm 0.128$ to $0.476 \pm 0.080 \mathrm{~g} / \mathrm{m}^{2} /$ day. The ferrous SOD decreased from $0.895 \pm 0.083$ to 0.226 $\pm 0.092 \mathrm{~g} / \mathrm{m}^{2} /$ day with $62.0 \%$ decrease. Site S12 was on the New Fuyang River, which is parallel to the Fuyang River. The total SOD, biological SOD, and ferrous SOD were all lower at the Fuyang River sites than at the Shaocun Canal sites. These changes in the SOD along the flow direction were probably mainly caused by the physicochemical characteristics of the water and sediment changing along the flow direction. Site S09 was in the upstream part of the Shaocun Canal, which mainly receives industrial waste from the leather industry in Xinji City and is very malodorous blackwater. The inputs of contaminants in surface water to the sediment gradually decrease moving from upstream to downstream, and some organic material will also have been mineralized. Contaminated sediment accumulated at site S09, causing the total SOD, biological SOD, and ferrous SOD to be higher at this site than at the other sites.

\section{Benthic organisms}

Only four kinds of benthos were collected at seven of 13 sites in the Ziya River watershed. There was even no benthos at the other six sites. The benthos orders had been identified as two types of Hemiptera, one type of Oligochaete, and one type of Gastropod, as shown in Table 3. The Chironomus larvae biomass (mean $1.35 \mathrm{~g} / \mathrm{m}^{2}$ ) was higher than the biomass of the other species. The biomasses of benthos were all at low levels, with an average of $1.35 \mathrm{~g} / \mathrm{m}^{2}$ for Chironomidae, $0.52 \mathrm{~g} / \mathrm{m}^{2}$ for Chaoborus, and $0.38 \mathrm{~g} / \mathrm{m}^{2}$ for Limnodrilus. There was a large range of benthos density which from 16 to 48 ind. $/ \mathrm{m}^{2}$. The highest densities of benthos was 448 ind. $/ \mathrm{m}^{2}$ found at site $\mathrm{S} 01$ and site S02, belonging to Chironomidae. Chironomidae and Chaoborus were found at higher population densities (mean 292 and 240 ind. $/ \mathrm{m}^{2}$, respectively) than were the other species. The two other types of benthos that were found were Limnodrilus and Alocinma longicornis.

\section{Discussion}

\section{SOD levels in the Ziya river watershed}

Despite the importance of accurately measuring the SOD, the SOD is often estimated using data from the literature because of the difficulty in obtaining a universally accepted standard SOD measurement (Bowman and Delfino 1980; Chau 2002). Matlock et al. (2003) found SOD for the Arroyo Colorado River of $0.13-1.36 \mathrm{~g} / \mathrm{m}^{2} /$ day. The Arroyo Colorado River is

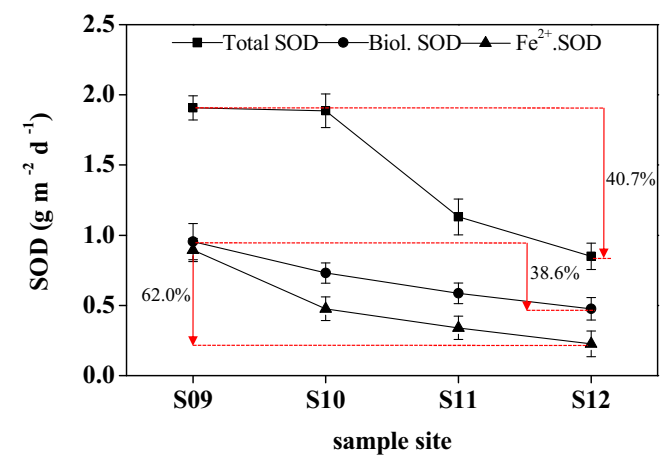

Fig. 4 Total, biological (Biol.), and ferrous $\left(\mathrm{Fe}^{2+}\right.$.) sediment oxygen demand (SOD) along the Shaocun Canal before it enters the Fuyang River. The graph presents the mean values and standard deviation $(n=3)$ 
Table 3 Biomasses and densities of benthic organisms at different sampling sites

\begin{tabular}{lllll}
\hline Orders & Species & Sample site & Biomass $\left(\mathrm{g} / \mathrm{m}^{2}\right)$ & Density (ind. $\left./ \mathrm{m}^{2}\right)$ \\
\hline Hemiptera & Chironomidae & S08 & 0.20 & 112 \\
& & $\mathrm{~S} 13$ & 0.29 & 160 \\
& & $\mathrm{~S} 02$ & 3.25 & 448 \\
& Average & $\mathrm{S} 01$ & 1.65 & 448 \\
Hemiptera & Chaoborus & $\mathrm{S} 05$ & 1.35 & 292 \\
Oligochaete & Limnodrilus & $\mathrm{S} 07$ & 0.52 & 240 \\
& & $\mathrm{~S} 06$ & 0.35 & 16 \\
& Average & & 0.41 & 48 \\
Gastropod & Alocinma longicornis & $\mathrm{S} 07$ & 0.38 & 32 \\
\hline
\end{tabular}

ind. individual, n.d. not detected polluted with municipal and agricultural wastewater. Liu and Chen (2012) found SOD for the Xindian River in Taiwan of $0.37-1.25 \mathrm{~g} / \mathrm{m}^{2} /$ day. The Xindian River has very high nutrient concentrations and a very low DO concentration (less than $1 \mathrm{mg} / \mathrm{L})$. Our results indicated that the SOD values in this study are similar to those that have previously been found in heavily polluted rivers. The SOD plays a stronger role in the oxygen balance of the Ziya River watershed than was previously believed.

\section{Biological and chemical contributions to the SOD}

The relative contributions of the biological SOD and chemical SOD have been found to be not uniform in different areas and water bodies. The mean contribution of the chemical SOD to the total SOD in the study area was $58.87 \%$, lower than that of $71 \%$ reported in Horseshoe Lake (Wang 1980) and $62 \%$ reported by Pamatmat (1971). Hargrave (1972) and Smith et al. (1973) found chemical SOD of 10-30\% and $22.1 \%$, respectively, of the total SOD. Liu (1973) found a biological SOD of more than $65 \%$ of the total SOD at the sediment surface. Brewer et al. (1977) found that the biological SOD contributed almost $91 \%$ of the total SOD. Belanger (1981) found that the biological SOD contributed $60-90 \%$ of the total SOD. Different sediment characteristics decided biological SOD and chemical SOD playing different roles in these samples. The chemical SOD was found to inversely correlate with the DO concentration in water, maybe because low DO concentration promoted the accumulation of reduced substances (Sommaruga 1991). The more severe the anoxic condition, the more chemical SOD is favored.

Iron, sulfide, and manganese may play different roles in sediments. The exchange of dissolved organic molecules and inorganic ions across the sediment-water interface is fundamental to the biological and geochemical processes that occur in rivers (Jørgensen and Revsbech 1985). Iron is often removed from iron-bearing water through the oxidation of ferrous iron by dissolved oxygen, then the resulting ferric oxide floc is removed by sedimentation or filtration (Stumm and Lee 1961). Thermodynamically, organic matter is used preferentially by iron-reducing bacteria rather than sulfatereducing bacteria. Iron-reducing bacteria can inhibit the activities of sulfate-reducing bacteria (Lovley and Phillips 1987). Therefore, dissimilatory iron reduction will promote the accumulation of reduced iron in sediment that is rich in active iron and organic matter. The chemical SOD will be related to the concentrations of the soluble and particulate-reduced iron compounds when sulfate dissimilatory reduction is inhibited. This may explain why the ferrous SOD was higher than the sulfide SOD in the Ziya River watershed. Manganese is not very abundant in the crust of the Earth (contributing $0.072 \%$ of the elements present, by mass), and the relative contribution of dissimilatory manganese reduction to the mineralization of organic matter is usually less than $10 \%$, and can be negligible (Bo et al. 1994; Thamdrup and Canfield 1996). The chemical oxidation rates of $\mathrm{NH}_{4}{ }^{+}, \mathrm{Mn}^{2+}$, and $\mathrm{CH}_{4}$ are much lower than bacterial oxidation rates (Jørgensen 1982). It is clear that the mineralization of organic carbon in sediment is the key process that governs the depletion of oxygen in sediment.

\section{Potential environmental effects of the SOD}

Sediment, being a reservoir of SOD, may retard the response of the water quality to river restoration measures. When considering at the potential effect of these SOD rates on water column DO concentrations, their influence was prominent. Hypothesized that the water quality had been improved, pollution sources had been cut off, yet contaminated sediments had not been restored; SOD would still strongly affect the DO concentrations in rivers. A hypothetical square meter of sediment overlain by water $0.63 \mathrm{~m}$ deep (the mean depth of water in the Ziya River watershed) containing an initial DO concentration of $5 \mathrm{mg} / \mathrm{L}$ (the Chinese Class III water standard, and the limit for fish conservation) would contain a total of $3150 \mathrm{mg}$ of DO. Assuming that no reaeration, photosynthesis, or water movement occurred, the available DO within the 
water column would be consumed in $76 \mathrm{~h}$ at the mean SOD rate of $0.993 \mathrm{~g} / \mathrm{m}^{2} /$ day. The DO would even be depleted in $40 \mathrm{~h}$ at the maximum SOD we measured in this study $\left(1.907 \mathrm{~g} / \mathrm{m}^{2} /\right.$ day $)$. It is rare that reaeration, photosynthesis, and water movement could occur in blackwater river systems, so the above hypothesis shows that managers should pay close attention to the influence of the SOD when developing water quality management protocols because the SOD plays a critical role in determining the DO concentration in river systems.

Appropriate DO concentrations are necessary for the survival, breeding, and development of aquatic organisms. Low DO concentrations will decrease biodiversity and species richness in river ecosystems, and will change the fish and benthic community structure (Gray et al. 2002; Pollock et al. 2007). Chironomidae were the dominant species in the Ziya River watershed. Chironomidae and Chaoborus having the high bearing dirty ability can be used as indicators of water pollution. Their relative higher density than other species indicated that there is a serious water pollution problem in the Ziya River watershed. It was clear that the high SOD and the low DO concentration at the sedimentwater interface resulted in quite low levels of biodiversity and species richness in the sediment in the Ziya River watershed.

Oxygen, nutrient, and reduced chemical species fluxes at the sediment-water interface are known to contribute to biogeochemical cycles in most shallow water systems (Berelson et al. 1998). In sediments underlying well oxygenated bottom waters, $\mathrm{O}_{2}$ is the ultimate electron acceptor of almost all electron equivalents released during the oxidation of organic matter (Holtappels et al. 2013). Oxygen is used by bacteria to oxidize organic carbon and is used in the abiotic or bacterial oxidation of reduced inorganic species, such as $\mathrm{Fe}(\mathrm{II}), \mathrm{Mn}(\mathrm{II})$, and $\mathrm{H}_{2} \mathrm{~S}$. These processes collectively provide the SOD, which may have a profound effect on the oxygen budget and the water quality of a river. Sediment plays a key role in liberating organic-bound nutrients to fuel primary production through the mineralization of organic matter accompanied by SOD processes (Brooks and Edgington 1994; Wollast 1991). SOD is a key cause for anoxic in rivers that can cause odors and release of dissolved phosphorus and metals to the water column (Richardson and Osborn 2014). Excess nitrogen and phosphorus are released directly into the overlying water, causing eutrophication of the river. Eutrophication causes more sedimentation of phytoplankton remains to occur (Chapra and Canale 1991). The remains of phytoplankton can form biodeposits that can affect the DO concentration by increasing the amount of organic material in the sediment and the subsequent decomposition of the organic material (Brooks and Edgington 1994;
Wollast 1991). This promotes the SOD to increase, potentially causing the low DO concentration in the water. Low DO concentration can in turn seriously affect biological processes either through direct toxic effects on fish and bottom organisms or indirectly through the production of toxic anaerobic mineralization by-products (Wang and Chapman 1999). Large allochthonous inputs of organic matter drive high respiration rates and lead to blackwater systems being very heterotrophic (Edwards and Meyer 1987; Meyer and Edwards 1990). These processes may have contributed to the oxygen depletion that has been found in the Ziya River watershed. In addition to the direct consumption of oxygen and the release of nutrients, the SOD can, through different pathways, have other effects on an ecosystem, including causing hydrogen sulfide to be released, methane to be produced, and phosphate to be retained in the sediment (Roden and Edmonds 1997; Roden and Wetzel 1996).

The high chemical SOD found in the Ziya River watershed, along with the anaerobic mineralization of the organic matter, could profoundly affect the biogeochemical cycles of the rivers, and this requires further study. Reaching or maintaining a sufficient DO level is often a focus of river management. Some useful approaches include decreasing external pollution loads, increasing the supply of DO through oxygenation or aeration (Singleton and Little 2006), and removing accumulated organic matter deposits by dredging the sediment (Annadotter et al. 1999).

\section{Conclusions}

We used inhibitor techniques to estimate different SOD components and to determine their relative contributions to the total SOD. The mean total, chemical, and biological SOD were $0.993,0.560$, and $0.433 \mathrm{~g} / \mathrm{m}^{2} /$ day, respectively. The chemical SOD contributed $58.87 \%$ of the total SOD, on average, representing the dominant component of the total SOD. The ferrous SOD contributed 33.26-96.79\% of the chemical SOD, and it was the dominant contributor to the chemical SOD. The sulfide SOD contributed $1.78-45.71 \%$ of the total SOD, lower than the ferrous SOD. The manganous SOD was generally negligible. The potential effects of SOD also have been considered. SOD may result in a low DO concentration at the sediment surface and a low biomass and benthos density in the sediment. Dominant chemical SOD processes would not only cause DO depletion in the overlying water but also cause nutrient and toxicant release. More attentions should be paid to the effects of SOD during river restoration operations. 
Acknowledgments This work was supported by the Water Pollution Control and Treatment National Science and Technology Major Project (2012ZX07203-006 and 2012ZX07203-003), the Dispersed Rural Sewage Treatment Technology Integration and Demonstration Projects (KZZD-EW-09), and the Rural Environment Comprehensive Regulation Science and Technology Major Engineering Project (2012BAJ21B0401 ), and the special fund from the State Key Joint Laboratory of Environment Simulation and Pollution Control (Project No. 15L01ESPC).

\section{References}

Annadotter H, Cronberg G, Aagren R, Lundstedt B, Nilsson P-Á, Ströbeck S (1999) Multiple techniques for lake restoration. Hydrobiologia 395(396):77-85

Bak F, Pfennig N (1991) Microbial sulfate reduction in littoral sediment of Lake Constance. FEMS Microbiol Lett 85:31-42

Barcelona MJ (1983) Sediment oxygen demand fractionation, kinetics and reduced chemical substances. Water Res 17:1081-1093

Belanger TV (1981) Benthic oxygen demand in lake Apopka, Florida. Water Res 15:267-274

Berelson W, Heggie D, Longmore A, Kilgore T, Nicholson G, Skyring G (1998) Benthic nutrient recycling in Port Phillip bay, Australia. Estuar Coast Shelf Sci 46:917-934

Bo T, Fossing H, Bo BJ (1994) Manganese, iron and sulfur cycling in a coastal marine sediment, Aarhus bay, Denmark. Geochim Cosmochim Acta 58:5115-5129

Bowman GT, Delfino JJ (1980) Sediment oxygen demand techniques: a review and comparison of laboratory and in situ systems. Water Res 14:491-499

Brewer WS, Abernathy A, Paynter M (1977) Oxygen consumption by freshwater sediments. Water Res 11:471-473

Brooks AS, Edgington DN (1994) Biogeochemical control of phosphorus cycling and primary production in Lake Michigan. Limnol Oceanogr 39:961-968

Chapra SC, Canale RP (1991) Long-term phenomenological model of phosphorus and oxygen for stratified lakes. Water Res 25:707-715

Chau K (2002) Field measurements of SOD and sediment nutrient fluxes in a land-locked embayment in Hong Kong. Adv Environ Res 6: $135-142$

Cox B (2003) A review of dissolved oxygen modelling techniques for lowland rivers. Sci Total Environ 314-316:303-334

Edwards R, Meyer J (1987) Metabolism of a sub-tropical low gradient black water river. Freshw Biol 17:251-263

Grashoff K, Kremling K, Ehrhard M (1983) Methods of seawater analysis, 2nd edn. Verlag Chemie, Weinheim

Gray JS, Wu RS, Or YY (2002) Effects of hypoxia and organic enrichment on the coastal marine environment. Mar Ecol Prog Ser 238: 249-279

Hargrave BT (1972) A comparison of sediment oxygen uptake, hypolimnetic oxygen deficit and primary production in Lake Esrom, Denmark. Verh Internat Verein Limnol 18: 134-139

Higashino M, Gantzer CJ, Stefan HG (2004) Unsteady diffusional mass transfer at the sediment/water interface: theory and significance for SOD measurement. Water Res 38:1-12

Holtappels M, Glud RN, Donis D, Liu B, Hume A, Wenzhöfer F, Kuypers MM (2013) Effects of transient bottom water currents and oxygen concentrations on benthic exchange rates as assessed by eddy correlation measurements. J Geophys Res Oceans 118: $1157-1169$
Hsieh Y, Yang C (1989) Diffusion methods for the determination of reduced inorganic sulfur species in sediments. Limnol Oceanogr 34:1126-1130

Jia Z, Liang T, Lam K, Liu F (1998) The role of acid volatile sulfide for toxicity of heavy metals in sediment of rivers in Hong Kong. Acta Sci Nat Univ Pekin 34:379-385

Jørgensen BB (1982) Mineralization of organic matter in the sea bedthe role of sulphate reduction. Nature 296:643-645

Jørgensen BB, Revsbech NP (1985) Diffusive boundary layers and the oxygen uptake of sediments and detritus 1. Limnol Oceanogr 30: $111-122$

Liu D (1973) Application of the manometric technique in the study of sediment oxygen depletion. Can Res Dev 6:35-37

Liu W-C, Chen W-B (2012) Monitoring sediment oxygen demand for assessment of dissolved oxygen distribution in river. Environ Monit Assess 184:5589-5599

Lovley DR, Phillips EJP (1987) Competitive mechanisms for inhibition of sulfate reduction and methane production in the zone of ferric iron reduction in sediments. Appl Environ Microbiol 53:2636-2641

Matlock MD, Kasprzak KR, Osborn GS (2003) Sediment oxygen demand in the Arroyo Colorado River. J Am Water Resour Assoc 39:267-275

Matzinger A, Müller B, Niederhauser P, Schmid M, Wüest A (2010) Hypolimnetic oxygen consumption by sediment-based reduced substances in former eutrophic lakes. Limnol Oceanogr 55(5):20732084

Meyer JL, Edwards RT (1990) Ecosystem metabolism and turnover of organic carbon along a blackwater river continuum. Ecology 71: 668-677

Pamatmat MM (1971) Oxygen consumption by the seabed. VI. Seasonal cycle of chemical oxidation and respiration in Puget Sound. Int Rev Gesamten Hydrobiol Hydrogr 56:769-793

Pollock M, Clarke L, Dube M (2007) The effects of hypoxia on fishes: from ecological relevance to physiological effects. Environ Rev 15(NA):1-14

Raun AL, Borum J, Sand-Jensen K (2010) Influence of sediment organic enrichment and water alkalinity on growth of aquatic isoetid and elodeid plants. Freshw Biol 55:1891-1904

Richardson GA, Osborn GS (2014) Effects of sediment resuspension and oxygenation on oxygen uptake rate, 2014 Montreal, Quebec Canada July 13-July 16, 2014. American Society of Agricultural and Biological Engineers, USA, p 1

Roden E, Edmonds J (1997) Phosphate mobilization in ironrich anaerobic sediments: microbial $\mathrm{Fe}$ (III) oxide reduction versus iron-sulfide formation. Arch Hydrobiol 139: $347-378$

Roden EE, Wetzel RG (1996) Organic carbon oxidation and suppression of methane production by microbial Fe (III) oxide reduction in vegetated and unvegetated freshwater wetland sediments. Limnol Oceanogr 41:1733-1748

Rutherford J, Wilcock R, Hickey C (1991) Deoxygenation in a mobilebed river-I. Field studies. Water Res 25:1487-1497

Singleton VL, Little JC (2006) Designing hypolimnetic aeration and oxygenation systems-a review. Environ Sci Technol 40: $7512-7520$

Smith KL, Rowe GT, Nichols JA (1973) Benthic community respiration near the Woods Hole sewage outfall. Estuar Coast Mar Sci 1:65-70

Sommaruga R (1991) Sediment oxygen demand in man-made Lake TonTon (Uruguay). Hydrobiologia 215:215-221

Stumm W, Lee GF (1961) Oxygenation of ferrous iron. Ind Eng Chem 53:143-146

Thamdrup B, Canfield DE (1996) Pathways of carbon oxidation in continental margin sediments off central Chile. Limnol Oceanogr 41: $1629-1650$ 
Todd MJ, Vellidis G, Lowrance RR, Pringle CM (2009) High sediment oxygen demand within an instream swamp in Southern Georgia: implications for low dissolved oxygen levels in coastal blackwater streams1. J Am Water Resour Assoc 45:1493-1507

Todd MJ, Lowrance RR, Goovaerts P, Vellidis G, Pringle CM (2010) Geostatistical modeling of the spatial distribution of sediment oxygen demand within a Coastal Plain blackwater watershed. Geoderma 159:53-62

Urban N, Brezonik P, Baker L, Sherman L (1994) Sulfate reduction and diffusion in sediments of Little Rock Lake, Wisconsin. Limnol Oceanogr 39:797-815
Veenstra JN, Nolen SL (1991) In-situ sediment oxygen demand in five southwestern U.S. lakes. Water Res 25:351-354

Wang W (1980) Fractionation of sediment oxygen demand. Water Res 14:603-612

Wang F, Chapman PM (1999) Biological implications of sulfide in sediment - a review focusing on sediment toxicity. Environ Toxicol Chem 18:2526-2532

Wollast R (1991) The coastal organic carbon cycle: fluxes, sources and sinks. In: Mantoura R, Martin J-M, Wollast R (eds) Ocean margin processes in global change. Wiley, New York, pp 365-381 